\title{
Characteristics of Aerosol and Effect of Aerosol-Radiation-Feedback in Handan, an Industrialized and Polluted City in China in Haze Episodes
}

\author{
Sen Yao ${ }^{1,2, *}$, Qianheng Wang ${ }^{1}$, Junmei Zhang ${ }^{1}$ and Ruinan Zhang ${ }^{1}$ \\ 1 School of Energy \& Environment, Zhongyuan University of Technology, Zhengzhou 450007, China; \\ 2020108262@zut.edu.cn (Q.W.); 6785@zut.edu.cn (J.Z.); 9789@zut.edu.cn (R.Z.) \\ 2 Key Laboratory of Beijing on Regional Air Pollution Control, Beijing University of Technology, \\ Beijing 100124, China \\ * Correspondence: 6797@zut.edu.cn
}

check for updates

Citation: Yao, S.; Wang, Q.; Zhang, J.; Zhang, R. Characteristics of Aerosol and Effect of Aerosol-Radiation-

Feedback in Handan, an

Industrialized and Polluted City in China in Haze Episodes. Atmosphere 2021, 12, 670. https://doi.org/ 10.3390/atmos12060670

Academic Editors: Makiko Nakata and Mizuo Kajino

Received: 18 March 2021

Accepted: 17 May 2021

Published: 24 May 2021

Publisher's Note: MDPI stays neutral with regard to jurisdictional claims in published maps and institutional affiliations.

Copyright: (C) 2021 by the authors Licensee MDPI, Basel, Switzerland. This article is an open access article distributed under the terms and conditions of the Creative Commons Attribution (CC BY) license (https:/ / creativecommons.org/licenses/by/ $4.0 /)$.

\begin{abstract}
In order to investigate the chemical characteristics of aerosol pollution including $\mathrm{PM}_{1}$ and $\mathrm{PM}_{2.5}$ in Handan, the offline sampling campaign was conducted and the concentrations of total water-soluble inorganic ions (TWSI), carbonaceous components (OC and EC) were analyzed. The average concentrations were $88.5 \mu \mathrm{g} / \mathrm{m}^{3}$ for $\mathrm{PM}_{1}$ and $122 \mu \mathrm{g} / \mathrm{m}^{3}$ for $\mathrm{PM}_{2.5}$, and the corresponding ratios of $\mathrm{PM}_{1}$ versus $\mathrm{PM}_{2.5}$ on non-pollution, mild-moderate pollution and heavy pollution were $0.67,0.70$ and 0.77 , respectively. TWSI and OC accounted for $43.2 \%$ and $15.4 \%$ in $\mathrm{PM}_{1}, 41.8 \%$ and $16.0 \%$ in $\mathrm{PM}_{2.5}$. Secondary components in $\mathrm{PM}_{2.5}$ and $\mathrm{PM}_{1}$ increased with heavy pollution, SNA $\left(\mathrm{SO}_{4}{ }^{2-}, \mathrm{NO}_{3}{ }^{-}\right.$and $\left.\mathrm{NH}_{4}{ }^{+}\right)$was enriched in $\mathrm{PM}_{1}$ but SOC (Secondary Organic Carbon) was more enriched in $\mathrm{PM}_{1-2.5}$. Furthermore, for evaluating the effect of aerosol feedback the WRF-Chem model was applied to identify the aerosol-radiation interaction of aerosol feedback influence on the $\mathrm{PM}_{2.5}$ concentration and various meteorological factors in Handan. The results indicated that the aerosol radiative effects will result in an average $32.62 \%\left(36.18 \mathrm{~W} / \mathrm{m}^{2}\right)$ decrease in downward short wave flux at ground surface (SWDOWN), an average $17.52 \%(39.15 \mathrm{~m})$ and $0.16 \%(0.44 \mathrm{~K})$ decrease in planetary boundary layer height(PBLH) and surface temperature (T2). The wind speed at $10 \mathrm{~m}$ (WS) and relative humidity $(\mathrm{RH})$ will be increased by about $4.16 \%(0.11 \mathrm{~m} / \mathrm{s})$ and $1.89 \%(0.78 \%)$, respectively.
\end{abstract}

Keywords: $\mathrm{PM}_{1} ; \mathrm{PM}_{2.5}$; water soluble inorganic ions; carbonaceous components; aerosol feedback

\section{Introduction}

Handan, a typical heavy industrial city located North China, is rich in iron ore and coal resources and its heavy industry as iron and steel, coking, power were highly developed. In 2017, Handan produced 36 million tons of crude steel and 12 million tons of coke, accounting for $45 \%$ of its GDP. However, affected by Stable weather conditions with high humidity and low wind speed combined with anthropogenic emissions [1], this city has been restricted by severe air quality problems especially particulate matter. Handan has the highest $\mathrm{PM}_{2.5}$ concentration in 74 key cities in China, which reached $86 \mu \mathrm{g} / \mathrm{m}^{3}$ in 2017, the average daily concentration is even as high as $316 \mu \mathrm{g} / \mathrm{m}^{3}$. Investigating characteristic of particulate matter pollution in Handan has great significance for revealing the causes of air pollution in developing countries and proposing emission reduction schemes. Some scholars have begun to discuss the topic of $\mathrm{PM}_{2.5}$ in Handan. Investigations based on model simulations [2] and studies on the spatial-temporal change and chemical characteristics of $\mathrm{PM}_{2.5}$ are conducted [3-6].

Due to the smaller particle size, larger specific surface area and higher number concentration, $\mathrm{PM}_{1}$ has greater impacts than $\mathrm{PM}_{2.5}$ on visibility and radiative climate forcing, further harmfully affect human health [7-10]. Furthermore, high concentration of aerosols has always strong feedback effect on meteorological factors in turn, by its feedback [11]. Many 
studies have shown that aerosol pollution is mainly influenced by weather constituents and anthropogenic activities [12-14]. Influenced by radiation feedback, meteorological conditions are increasingly steady, suppressing pollutants diffusion and then aggravate heavy pollution. However, our knowledge of $\mathrm{PM}_{1}$ pollution and its effect on meteorological factors in Handan region remains poor. Therefore, it is fundamental to obtain the $\mathrm{PM}_{1}$ and $\mathrm{PM}_{2.5}$ chemical components evolution characteristics including water soluble inorganic ions and carbonaceous components, and illustrate how aerosol feedback affect meteorological elements, in the heavy polluted city, Handan.

In this study, the $\mathrm{PM}_{2.5}$ and $\mathrm{PM}_{1}$ samples were collected in Handan from 15 October 2017 to 15 November 2017 and from 29 December 2017 to 26 January 2018. The observed $\mathrm{PM}_{2.5}$ and meteorological data were systematically analyzed. We also applied the Weather Research and Forecasting model coupled to Chemistry (WRF-Chem) model over the northern China to exhibit more exact data on aerosol feedbacks [15]. The impacts of aerosol feedbacks on meteorology including solar radiation (SWDOWN), temperature (T2), wind speed (WS), relative humidity (RH) and planetary boundary layer height (PBLH), as well as the concentration of $\mathrm{PM}_{2.5}$ were assessed via the scenario simulations.

The objectives of this paper are as follows: (1) to determine the characteristics of chemical compositions, such as water-soluble ions and carbonaceous components in $\mathrm{PM}_{1}$ and $\mathrm{PM}_{2.5}$; (2) to elucidate the impact of aerosol feedback mechanism on the $\mathrm{PM}_{2.5}$ concentration and various meteorological factors, such as T2, WS, PBLH and RH.

\section{Material and Methodology}

\subsection{Sampling and Chemical Analysis}

$\mathrm{PM}_{2.5}$ and $\mathrm{PM}_{1}$ was sampled during the adjacent periods, from 15 October 2017 to 15 November 2017 and from 29 December 2017 to 26 January 2018. A total of 61 daily samples were collected by a medium volume sampler (URG-3000ABC, USA) with a flow rate of 16.7 L/min. For the investigation of PM mass and inorganic particles the Teflon filters (47 mm, Whatman, UK) were utilized, while for the examination of carbonaceous species the quartz filters ( $47 \mathrm{~mm}$, Whatman, UK) were used [16-18]. All filters were stored at $<4{ }^{\circ} \mathrm{C}$ before investigation. The samples were collected on the rooftop ( $35 \mathrm{~m}$ above ground) of a building in Environmental Protection Bureau of Handan $\left(36^{\circ} 61^{\prime} \mathrm{N}, 115^{\circ} 51^{\prime} \mathrm{E}\right)$, as shown in Figure 1c, surrounded with residential and traffic sources, but without remarkable industrial enterprise. Representing pollution characteristics of morning peak, the sampling time was from 10:00 a.m. to 9:00 a.m. of the next day. When special situation (rainy day and equipment failure) arose, we would adjust sampling time temporarily.
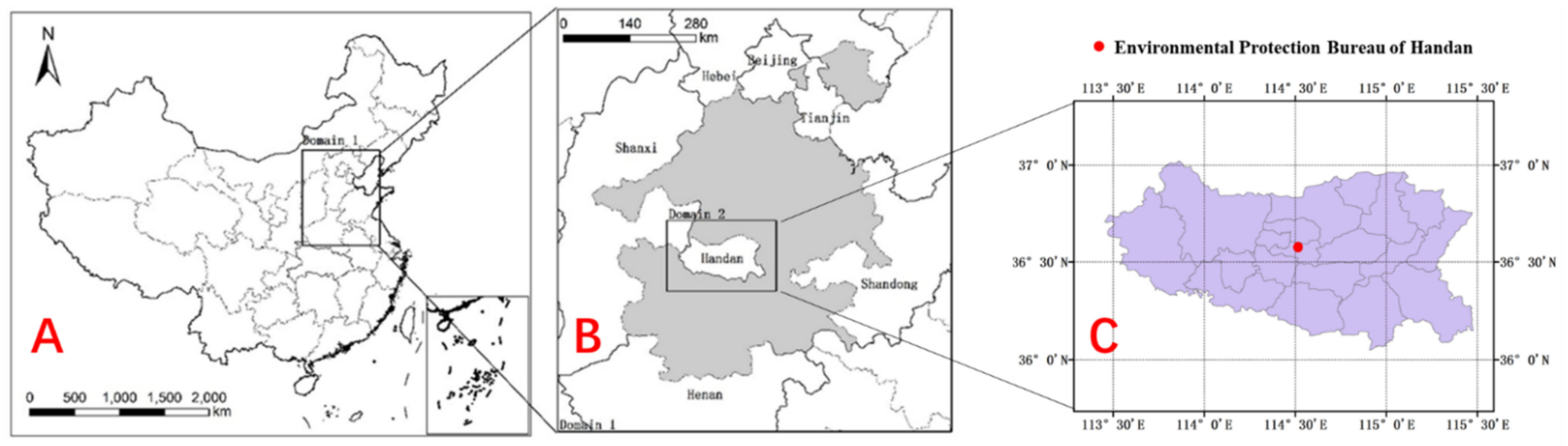

Figure 1. Location of the sampling sites (c) and WRF-Chem modeling domain setting $(\mathbf{a}, \mathbf{b})$. The grey areas are the other " $2+26$ " cities in Beijing-Tianjin-Hebei region and surrounding areas.

For analyzing PM mass concentrations, we used a microbalance (Sartorius-Denver TB$215 \mathrm{D}$, accuracy, $0.01 \mathrm{mg}$ ) to weigh Teflon filters before and after each sampling under $48 \mathrm{~h}$ stable condition( $\mathrm{T}=20 \pm 5{ }^{\circ} \mathrm{C}$ and $\mathrm{RH}=40 \pm 2 \%$ ) (Yang et al., 2017). Half of each Teflon filter sample was extracted ultrasonically and the concentrations of eleven water-soluble 
ions $\left(\mathrm{Na}^{+}, \mathrm{K}^{+}, \mathrm{Ca}^{2+}, \mathrm{Mg}^{2+}, \mathrm{NH}_{4}{ }^{+}, \mathrm{F}^{-}, \mathrm{Cl}^{-}, \mathrm{NO}_{2}{ }^{-}, \mathrm{NO}_{3}{ }^{-}, \mathrm{SO}_{4}{ }^{2-}\right.$ ) were analyzed by Ion Chromatography (861 Advanced Compact IC, Metrohm) (Jia et al., 2018; Wang et al., 2017; Wang et al., 2018). Element carbon (EC) and organic carbon (OC) content was analyzed by thermal-optical reflectance carbon analysis method using DRI2001A (Chow et al., 2004). More detailed descriptions of the operation method was described in the Supplementary File and previous works (Wen et al., 2018).

\subsection{Meteorological Data}

Meteorological parameters including wind speed, wind direction, ground temperature, relative humidity, visibility and precipitation amount were obtained from the "China meteorological Information Centre" website (http:// data.cma.cn, accessed on 12 May 2020). Data obtained from this website were supplied by Handan weather station which is located in Congtai Park $\left(36^{\circ} 62^{\prime} \mathrm{N}, 115^{\circ} 49^{\prime} \mathrm{E}\right)$. All of the meteorological data were arranged according to the $\mathrm{PM}_{2.5}$ sampling time (10:00 a.m. to 9:00 a.m. of the next day).

\subsection{Model Design and Verification}

The WRF-Chem version 3.5.1 was applied for analyzing the aerosol-radiation feedback effect on the meteorological factors. In this study, a two-level nested computational domains were established with a spatial resolution of $9 \mathrm{~km} \times 9 \mathrm{~km}$ for the large domain and a spatial resolution of $3 \mathrm{~km} \times 3 \mathrm{~km}$ for the inner domain, which are denoted as Domain 1 and Domain 2, respectively (as shown in Figure 1a,b). The simulation period is consistent with the sampling time. Domain 1 covered " $2+26$ " cities in Beijing-Tianjin-Hebei region and surrounding areas. Domain 2 covered Handan city and its surrounding cities including Anyang, Xingtai, Liaocheng, Yangquan and Puyang.

The emission inventory was calculated dependent on raw emissions data, emission coefficients and activity categories. More detailed depictions of the complete emission inventory which were utilized in this study could be found in previous works published by the researchers in the Key Laboratory of Beijing on Regional Air Pollution Control [19-21] and the raw emissions data in emission inventory were updated to 2017.

In this study, we employed National Center for Environmental Prediction (NCEP) Final Analysis (FNL) reanalysis data sets as the meteorological initial (IC) and boundary conditions (BC). The Carbon-Bond Mechanism version Z (CBMZ) [22] coupled with Model for Simulating Aerosol Interactions and Chemistry (MOSAIC) using 4 sectional aerosol bins were chosen as the gas-phase chemical mechanism and aerosol parameterization scheme [23]. We used Fast-J photolysis scheme to calculate photolysis rates. Furthermore, some physics options are selected in the simulation, such as Lin microphysics [21], the Goddard short wave scheme [24], RRTM long wave scheme [25], Noah land surface model, the Yonsei University (YSU) planetary boundary layer scheme [26] and the Grell-Devenyi cumulus parameterization.

To represent the actual PM pollution process, we designed Scenario BASE which includes aerosol-radiation feedback (aerosol-meteorology direct feedbacks on air quality was turned on, aer_ra_feedback $=1$ in the WRF-Chem model) and various control measures were executed. To assess the effect, we also designed the Scenario NF without aerosol-radiation feedback (aer_ra_feedback $=0$ in the WRF-Chem model). The results of Scenario NF simulation were compared with the results of Scenario BASE demonstrating the effectiveness of aerosol radiative feedback.

For evaluating the performance of the WRF-chem in simulating both $\mathrm{PM}_{2.5}$ concentrations and meteorological variables, the time series of the observed and predicted results was obtained and presented in Supplementary Information (Figure S1).

\section{Results and Discussion}

3.1. Characteristics of $P M_{1}$ and $P M_{2.5}$

The average concentrations of $\mathrm{PM}_{2.5}$ and $\mathrm{PM}_{1}$ for the entire sampling period were $122.0 \mu \mathrm{g} / \mathrm{m}^{3}$ and $88.5 \mu \mathrm{g} / \mathrm{m}^{3}$, respectively. $\mathrm{PM}_{2.5}$ mass concentration far exceeds the 
Chinese National Ambient Air Quality Standards (CNAAQS) (GB3095-2012) Grade II $\left(35 \mu \mathrm{g} / \mathrm{m}^{3}\right.$ for the annual average of $\mathrm{PM}_{2.5}$ ), for approximately 3.5 times. A number of measures have been recently taken to reduce pollution from anthropogenic sources, consequently, $\mathrm{PM}_{2.5}$ concentration of Handan demonstrates a decreasing trend with annual average concentrations for the urban area moving from $139 \mu \mathrm{g} / \mathrm{m}^{3}$ in 2013 to $86 \mu \mathrm{g} / \mathrm{m}^{3}$ in 2017.

To investigate general distinction of $\mathrm{PM}_{1}$ and $\mathrm{PM}_{2.5}$ in clean and polluted days $\mathrm{PM}_{1}$ and $\mathrm{PM}_{2.5}$ daily mass concentration was tested. According to the $\mathrm{PM}_{2.5}$ concentration we defined haze episodes as non-pollution $\left(0<\mathrm{PM}_{2.5} \leq 75 \mu \mathrm{g} / \mathrm{m}^{3}\right)$, mild-moderate pollution $\left(75 \mu \mathrm{g} / \mathrm{m}^{3}<\mathrm{PM}_{2.5} \leq 150 \mu \mathrm{g} / \mathrm{m}^{3}\right)$ and heavy pollution $\left(150 \mu \mathrm{g} / \mathrm{m}^{3}<\mathrm{PM}_{2.5}\right)$, as shown in Table 1. $\mathrm{PM}_{1}$ on Non-pollution (NP), Mild-moderate pollution (MP) and heavy pollution (HP) were $34.8,80.1$ and $165.6 \mu \mathrm{g} / \mathrm{m}^{3}$, respectively, while those of $\mathrm{PM}_{2.5}$ were $51.6,114$ and $216 \mu \mathrm{g} / \mathrm{m}^{3}$. The relating proportions of $\mathrm{PM}_{1} / \mathrm{PM}_{2.5}$ on NP, MP and HP were 0.67, 0.70 and 0.77 , respectively. The results suggested that $\mathrm{PM}_{1}$ contributed the most of $\mathrm{PM}_{2.5}$, as the pollution got worse, the proportion of $\mathrm{PM}_{1}$ to $\mathrm{PM}_{2.5}$ increased. Compared with other research which elaborated the proportions of $\mathrm{PM}_{1} / \mathrm{PM}_{2.5}$ in China northern Cities, the ratios of Handan are close to Beijing (0.75), Shijiazhuang (0.74), Tangshan (0.72) and Qingdao (0.76) that located in the northern China. while Compared with some metropolis in southern China, the ratios of Handan are lower than at Jinsha (0.90), Guilin (0.90), Dongtan (0.90), Changde (0.91), Chengdu (0.91), Nanning $(0.91)$ [27,28]. In order to better illustrate the differences under different pollution levels, we characterized the ratio of the concentration in pollution periods over that on NP as the enrichment factor (EF). EFs of $\mathrm{PM}_{1}$ on MP and HP were 2.19 and 3.75, respectively, which of $\mathrm{PM}_{2.5}$ were 2.21 and 4.18. As a result of the EF of $\mathrm{PM}_{2.5}$ was higher than $\mathrm{PM}_{1}$, especially on $\mathrm{HP}$, we assumed that the growth of $\mathrm{PM}_{1-2.5}$ was bigger than for $\mathrm{PM}_{1}$. This phenomenon was predictable with the outcomes amid serious air pollution in Beijing [29], which showed that $\mathrm{PM}_{1 \cdot 1-2.1}$ increased faster than $\mathrm{PM}_{1}$.1. In this research, the peak mass concentration of particles shifted from $0.43-0.65 \mu \mathrm{m}$ on clean days to $0.65-1.1 \mu \mathrm{m}$ on lightly polluted days and to $1.1-2.1 \mu \mathrm{m}$ on heavily polluted days.

Table 1. Concentrations of $\mathrm{PM}_{1}$ and $\mathrm{PM}_{2.5}$ on non-pollution, mild-moderate pollution and heavy pollution in Handan in the period from 15 October to 15 November 2017 and from 29 December 2017 to 26 January 2018.

\begin{tabular}{ccccc}
\hline Classification & Number & $\mathbf{P M}_{\mathbf{1}}\left(\boldsymbol{\mu g} / \mathbf{m}^{\mathbf{3}}\right)$ & $\mathbf{P M}_{\mathbf{2 . 5}}\left(\boldsymbol{\mu g} / \mathbf{m}^{\mathbf{3}}\right)$ & $\mathbf{P M}_{\mathbf{1}} / \mathbf{P M}_{\mathbf{2 . 5}}$ \\
\hline Non-pollution (NP) & 17 & $34.8 \pm 10.9$ & $51.6 \pm 13.4$ & $0.67 \pm 0.09$ \\
Mild-moderate & 29 & $80.1 \pm 18.6$ & $114.2 \pm 20.7$ & $0.70 \pm 0.09$ \\
pollution (MP) & 15 & $169.6 \pm 33.6$ & $215.6 \pm 52.5$ & $0.77 \pm 0.07$ \\
Heavy pollution (HP) & 61 & $88.5 \pm 44.5$ & $122 \pm 67.2$ & $0.73 \pm 0.1$ \\
Entire & & & &
\end{tabular}

\subsection{Water Soluble Inorganic Ions in $P M_{1}$ and $P M_{2.5}$}

The total water-soluble inorganic ions (TWSI) were the major chemical species for $\mathrm{PM}_{1}$ and $\mathrm{PM}_{2.5}$, accounted for $43.2 \%$ and $41.8 \%$ in $\mathrm{PM}_{1}$ and $\mathrm{PM}_{2.5}$. Water soluble ion species in both $\mathrm{PM}_{1}$ and $\mathrm{PM}_{2.5}$ on NP, MP and HP during Sampling period in Handan are illustrated in Figure 2. The TWSI in $\mathrm{PM}_{1}$ on NP, MP and HP were $9.81,30.2$ and $61.5 \mu \mathrm{g} / \mathrm{m}^{3}$, while those in $\mathrm{PM}_{2.5}$ were 21.9, 50.9 and $108 \mu \mathrm{g} / \mathrm{m}^{3}$, respectively, demonstrating that TWSIs are more easily enriched in $\mathrm{PM}_{1}$. SNA $\left(\mathrm{SO}_{4}{ }^{2-}, \mathrm{NO}_{3}{ }^{-}\right.$and $\left.\mathrm{NH}_{4}{ }^{+}\right)$formed from the precursors such as $\mathrm{SO}_{2}, \mathrm{NO}_{2}$ and $\mathrm{NH}_{3}$ and accounted more than $80 \%$ in TWSIs of both $\mathrm{PM}_{1}$ and $\mathrm{PM}_{2.5}$ on clean and polluted days. Both on clean and hazed days, the concentration of $\mathrm{NO}_{3}{ }^{-}$was higher than $\mathrm{SO}_{4}{ }^{2-}$ in $\mathrm{PM}_{1}$ and $\mathrm{PM}_{2.5}$, it was the most abundant among SNA except in $\mathrm{PM}_{1}$ on NP. In this study, EFs of $\mathrm{SO}_{4}{ }^{2-}, \mathrm{NO}_{3}{ }^{-}$and $\mathrm{NH}_{4}{ }^{+}$in $\mathrm{PM}_{2.5}$ on MP were 2.47, 3.01 and 2.12, and on $\mathrm{HP}$ were 4.79, 6.42 and 4.39. While EFs of $\mathrm{SO}_{4}{ }^{2-}, \mathrm{NO}_{3}{ }^{-}$and $\mathrm{NH}_{4}{ }^{+}$in $\mathrm{PM}_{1}$ on $\mathrm{MP}$ were $3.70,3.86$ and 2.76, and on $\mathrm{HP}$ were 7.05, 8.10 and 5.50, respectively. On haze 
episodes, $\mathrm{EFs}$ of $\mathrm{SO}_{4}{ }^{2-}, \mathrm{NO}_{3}{ }^{-}$and $\mathrm{NH}_{4}{ }^{+}$in $\mathrm{PM}_{1}$ were higher than for $\mathrm{PM}_{1-2.5}$ (i.e., $\mathrm{SNA}$ increased more in $\mathrm{PM}_{1}$ ).

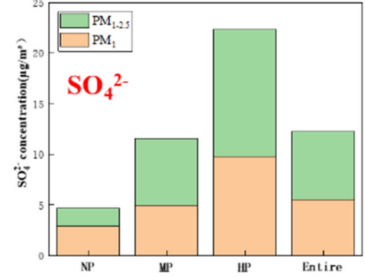

(a)

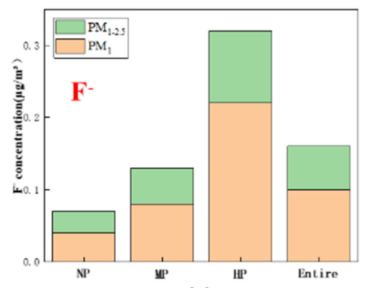

(e)

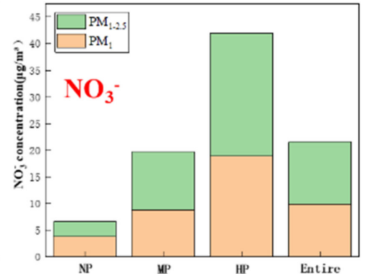

(b)

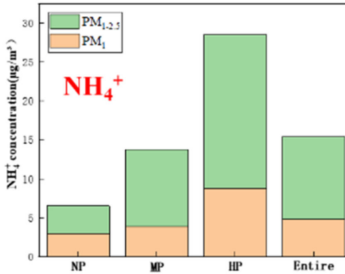

(c)

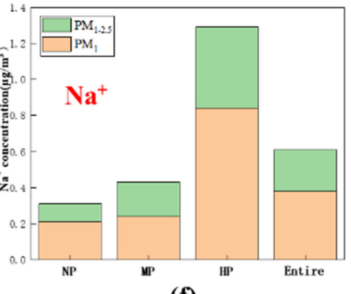

(f)

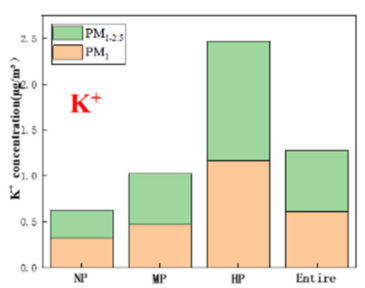

(g)

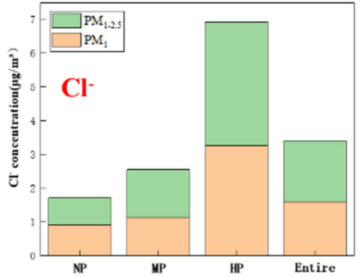

(d)

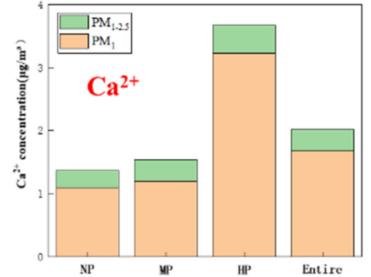

(h)

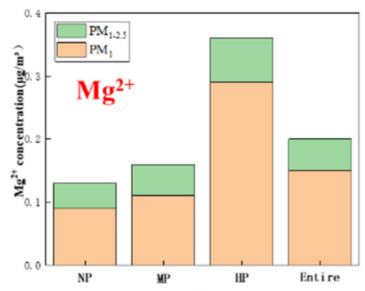

(i)

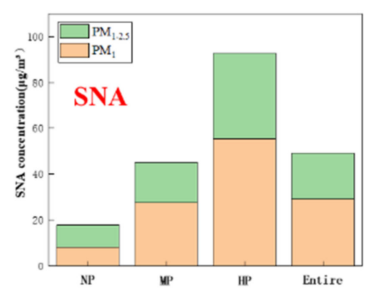

(j)

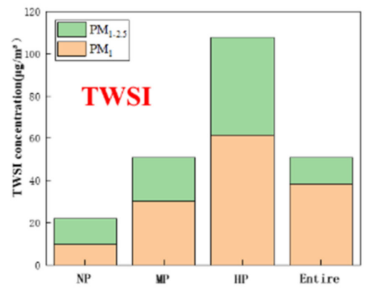

(k)

Figure 2. Concentrations of $\mathrm{SO}_{4}{ }^{2-}, \mathrm{NO}_{3}{ }^{-}, \mathrm{NH}_{4}{ }^{+}, \mathrm{Cl}^{-}, \mathrm{F}^{-}, \mathrm{Na}^{+}, \mathrm{K}^{+}, \mathrm{Ca}^{2+}, \mathrm{Mg}^{2+}, \mathrm{SNA}$, TWSI (a-k) in $\mathrm{PM}_{1}$ and $\mathrm{PM}_{1-2.5}$ on non-pollution, mild-moderate pollution and heavy pollution in Handan in the period from 15 October to 15 November 2017 and from 29 December 2017 to 26 January 2018.

Compared with previous studies, the differences for $\mathrm{NO}_{3}{ }^{-}$and $\mathrm{SO}_{4}{ }^{2-}$ are quite large, and nitrate had replaced $\mathrm{SO}_{4}{ }^{2-}$ as the most abundant component. Zhao's studies [30] pointed out that most of the $\mathrm{SO}_{4}{ }^{2-}$ in Handan comes from local emissions. In recent years, reduction of coal consumption, improvement of desulfurization technology and upgrading of clean energy dosage have brought about a sharp drop in $\mathrm{SO}_{4}{ }^{2-}$ concentration. We usually regarded the ratio of $\mathrm{NO}_{3}{ }^{-} / \mathrm{SO}_{4}{ }^{2-}$ as evidence of whether PM contributed by mobile or stationary sources [31], it is remarkable that $\mathrm{NO}_{3}{ }^{-} / \mathrm{SO}_{4}{ }^{2-}$ in $\mathrm{PM}_{2.5}$ and $\mathrm{PM}_{1}$ expanded with intensification of air pollution, we can infer that vehicles contributed much to $\mathrm{PM}_{2.5}$ and $\mathrm{PM}_{1}$ on polluted days and replacing coal with natural gas also increased $\mathrm{NO}_{2}$ emissions and decreased $\mathrm{SO}_{2}$ emissions. For estimating nitrogen and sulfur reaction degree, previous studies had defined nitrogen oxidation ratio $\left(\mathrm{NOR}=\mathrm{nNO}_{3}{ }^{-} /\left(\mathrm{nNO}_{3}{ }^{-}+\mathrm{nNO}_{2}\right), \mathrm{n}\right.$ refers to molar concentration) and sulfur oxidation ratio $\left(\mathrm{SOR}=n \mathrm{SO}_{4}{ }^{2-} /\left(\mathrm{nSO}_{4}{ }^{2-}+\mathrm{nSO}_{2}\right)\right)$ [32]. As indicated in Figure 3, NOR in $\mathrm{PM}_{2.5}$ was higher than in $\mathrm{PM}_{1}$ and increased in both $\mathrm{PM}_{1}$ and $\mathrm{PM}_{2.5}$ with worse pollution, nevertheless, SOR was highest on MP both $\mathrm{PM}_{1}$ and $\mathrm{PM}_{2.5}$. In this investigation, $\mathrm{SOR}$ in both $\mathrm{PM}_{1}$ and $\mathrm{PM}_{2.5}$ was higher than NOR, as concentration of $\mathrm{NO}_{2}\left(63.8 \mu \mathrm{g} / \mathrm{m}^{3}\right)$ was higher than $\mathrm{SO}_{2}\left(26.0 \mu \mathrm{g} / \mathrm{m}^{3}\right)$, we had got a higher observation value of $\mathrm{NO}_{3}{ }^{-}$than $\mathrm{SO}_{4}{ }^{2-}$. Scholars [32,33] discovered that haze pollution benefited from formation of $\mathrm{NO}_{3}{ }^{-}$, in addition, high concentrations of $\mathrm{NOx}$ promoted the conversion of $\mathrm{SO}_{2}$ to $\mathrm{SO}_{4}{ }^{2-}$ [34].

We also calculated the molar equivalent ratio of $n \mathrm{NH}_{4}{ }^{+} /\left(\mathrm{nNO}_{3}{ }^{-}+\mathrm{nSO}_{4}{ }^{2-}\right)$ to get the information on connection of species in soluble fraction of PM. Both in $\mathrm{PM}_{2.5}$ and $\mathrm{PM}_{1}$, $\mathrm{nNH}_{4}{ }^{+} /\left(\mathrm{NO}_{3}{ }^{-}+\mathrm{nSO}_{4}{ }^{2-}\right)$ on clean days and polluted days was larger than 1 , demonstrating that $\mathrm{NH}_{4} \mathrm{NO}_{3}$ and $\left(\mathrm{NH}_{4}\right)_{2} \mathrm{SO}_{4}$ were major form of SNA in $\mathrm{PM}_{2.5}$ and $\mathrm{PM}_{1}$. The presence of $\mathrm{NH}_{4} \mathrm{NO}_{3}$ is positive for water take-up and visibility decrease, it weaken the surface solar 
radiation by the feedback effect of particulate matter, the boundary layer height and wind speed decrease, further aggravated air contamination [35-37].

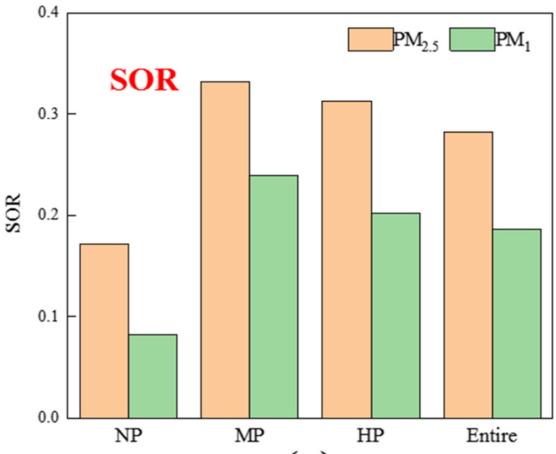

(a)

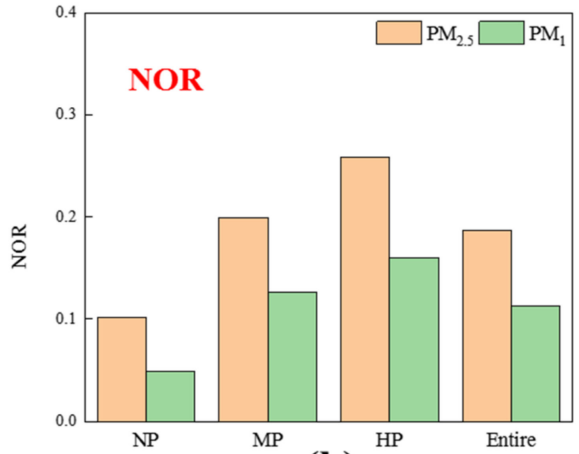

(b)

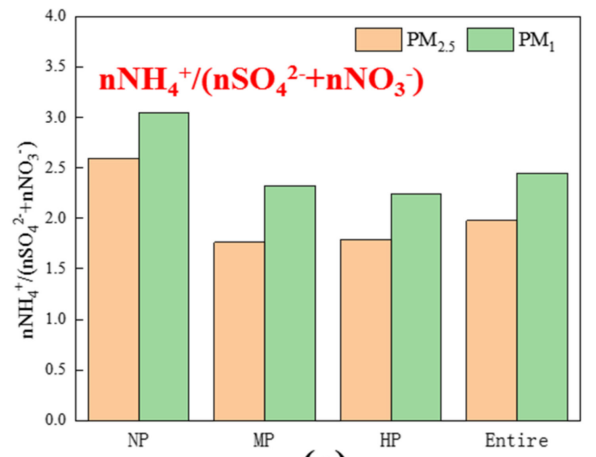

(c)

Figure 3. $\mathrm{NOR}(\mathbf{a}), \mathrm{SOR}(\mathbf{b}), \mathrm{nNH}_{4}{ }^{+} /\left(\mathrm{nNO}_{3}{ }^{-}+\mathrm{nSO}_{4}{ }^{2-}\right)$ (c) in $\mathrm{PM}_{1}$ and $\mathrm{PM}_{1-2.5}$ on non-pollution, mild-moderate pollution and heavy pollution in Handan during the investigation period.

As a tracer component of coal utilization [16,38], $\mathrm{Cl}^{-}$increased significantly in polluted days. EFs of $\mathrm{Cl}^{-}$in $\mathrm{PM}_{1}$ on MP and $\mathrm{HP}$ were 1.76 and 4.56, respectively, while those in $\mathrm{PM}_{2.5}$ were 1.45 and 4.02 . This phenomenon explained that coal combustion had a more significant contribution. In addition, EFs of $\mathrm{K}+$ in $\mathrm{PM}_{2.5}$ on MP and HP were 1.64 and 3.92, respectively, lower than those in $\mathrm{PM}_{1}$ (1.84 and 4.23). Biomass burning of straw and fallen leaves is the primary source of $\mathrm{K}^{+}$[38], the $\mathrm{EF}$ of $\mathrm{K}$ increased rapidly on the polluted day, indicating that the pollution may be accompanied by biomass combustion emissions. True to form, $\mathrm{Ca}^{2+}$ and $\mathrm{Mg}^{2+}$ are crustal ions corresponded like fly ash and construction dust in urban aerosols. On the other hand, the application of a large amount of limestone gypsum desulphurization process promoted the discharge of calcium ions, increased of alkali metal elements such as $\mathrm{K}, \mathrm{Mg}$ and Ca may be related to the use of desulfurizer.

\subsection{Carbonaceous Components in $P M_{1}$ and $P M_{2.5}$}

During the campaign, OC represents $15.4 \%$ in $\mathrm{PM}_{1}$ and $16 \%$ in $\mathrm{PM}_{2.5}$; and EC $3.4 \%$ in $\mathrm{PM}_{1}$ and $3.9 \%$ in $\mathrm{PM}_{2.5}$. As shown in Figure 4, $\mathrm{OC}$ in $\mathrm{PM}_{1}$ increased from $7.38 \mu \mathrm{g} / \mathrm{m}^{3}$ on NP to $11.8 \mu \mathrm{g} / \mathrm{m}^{3}$ on MP, and increased to $24.3 \mu \mathrm{g} / \mathrm{m}^{3}$ on HP. While OC in $\mathrm{PM}_{2.5}$ were $11.2,18.1$ and $31.5 \mu \mathrm{g} / \mathrm{m}^{3}$ on NP, MP and HP, respectively. In terms of EC, it were 1.94 , 3.93 and $5.41 \mu \mathrm{g} / \mathrm{m}^{3}$ on NP, MP and HP in $\mathrm{PM}_{1}$, while were $2.53,4.19$ and $5.80 \mu \mathrm{g} / \mathrm{m}^{3}$ in $\mathrm{PM}_{2.5}$, respectively. However, it is noteworthy that proportion of Total Carbon Aerosol $(\mathrm{TCA}=1.6 \times \mathrm{OC}+\mathrm{EC})[39,40]$ in $\mathrm{PM}$ were stable, which were $28.6 \%$ for $\mathrm{PM}_{1}$ and $29.0 \%$ for $\mathrm{PM}_{2.5}$ on both polluted and clean days. Furthermore, ratios of OC/EC in $\mathrm{PM}_{1}$ on NP, MP and HP, were 4.25, 4.40 and 5.70, respectively, while those in $\mathrm{PM}_{2.5}$ were $4.09,4.33$ and 5.54. The ratio of OC/EC increased with the increased pollution, we could deduce that secondary formation might be main cause of increased pollution in Handan.

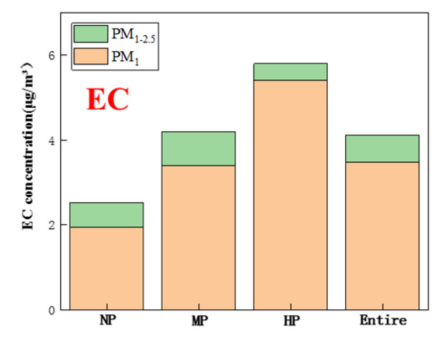

(a)

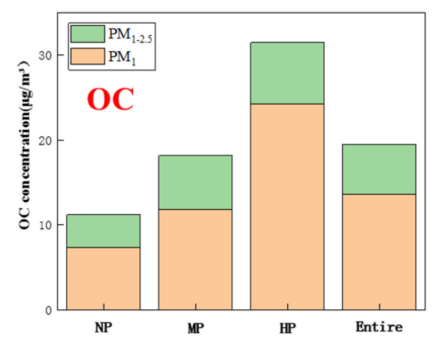

(b)

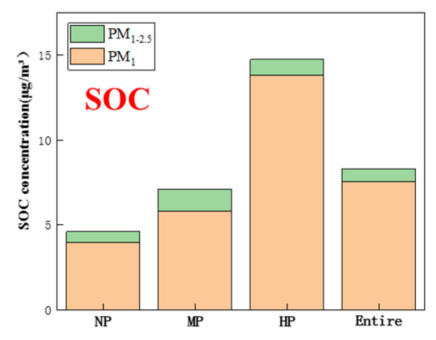

(c)

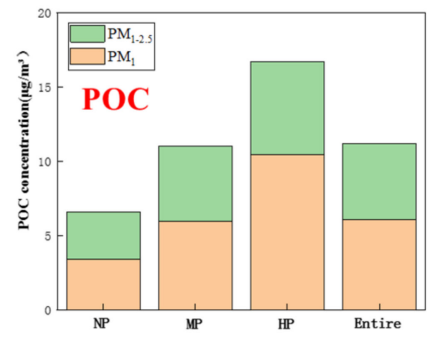

(d)

Figure 4. Concentrations of elemental carbon (a), organic carbon (b), secondary organic carbon (c), primary organic carbon (d) in $\mathrm{PM}_{1}$ and $\mathrm{PM}_{1-2.5}$ on non-pollution, mild-moderate pollution and heavy pollution in Handan in the period from 15 October to 15 November 2017 and from 29 December 2017 to 26 January 2018. 
In this study, $\mathrm{OC}$ and $\mathrm{EC}$ in $\mathrm{PM}_{1}$ or $\mathrm{PM}_{2.5}$ both had distinctly strong correlations (R2 was all above 0.70), as shown in Figure 5, which implying that these constituents might come from fossil fuel combustion. Furthermore, the meteorological conditions including high temperature and humidity could accelerate the formation of secondary organic materials, which deteriorated the correlation to a certain extent [41]. Ratio of OC/EC, which is above 2 in this paper, manifested that Secondary Organic Carbon (SOC) was manly affected by secondary reaction processes such as photochemical reaction and liquid phase reaction. This phenomenon showed that the sources of OC and EC were different, it is contradictory to the higher correlation coefficient between OC and EC, therefore, we inferred that the correlation between OC and EC is not the only criterion for determining whether $\mathrm{OC}$ and $\mathrm{EC}$ had similar sources, and other factors also affect the source of the carbonaceous particles.

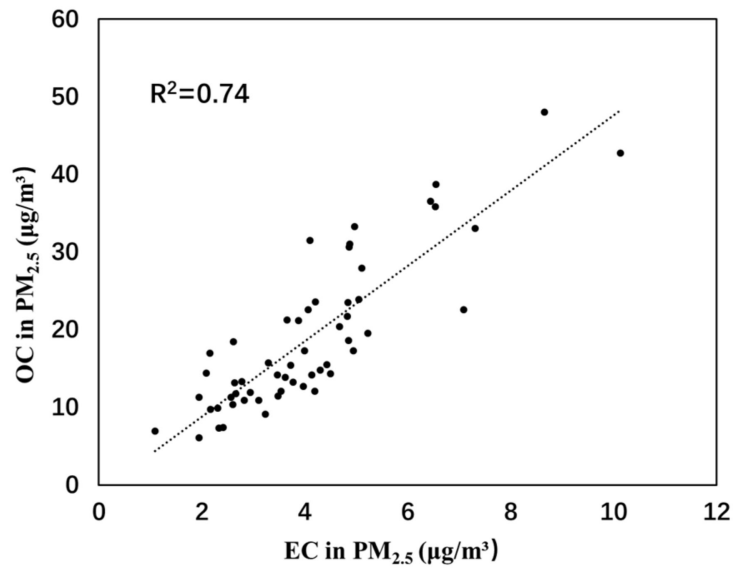

(a)

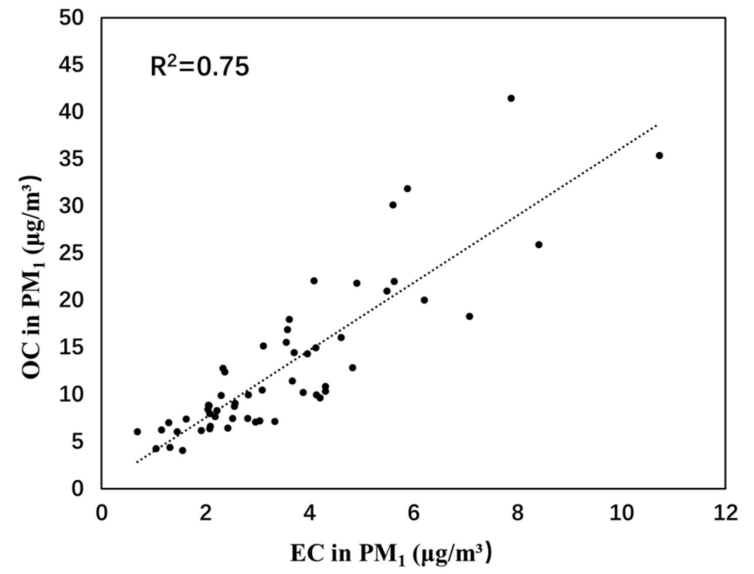

(b)

Figure 5. The relationship between $\mathrm{OC}$ and $\mathrm{EC}$ in $\mathrm{PM}_{2.5}$ (a) and $\mathrm{PM}_{1}$ (b) in Handan in the period from 15 October to 15 November 2017 and from 29 December 2017 to 26 January 2018.

In this work, we applied EC-based theory [42] to discuss Secondary Organic Carbon (SOC), calculated Primary Organic Carbon $(\mathrm{POC})$ by $\mathrm{EC} \times(\mathrm{OC} / \mathrm{EC}) \mathrm{min}$, and achieved SOC by OC minus POC. As shown in Figure 4, SOC in $\mathrm{PM}_{1}$ on NP, MP and HP were 3.97, 5.80 and $13.8 \mu \mathrm{g} / \mathrm{m}^{3}$, respectively. Accordingly, POC in $\mathrm{PM}_{1}$ on NP, MP and HP were $3.41,5.98$ and $10.5 \mu \mathrm{g} / \mathrm{m}^{3}$, respectively. On polluted days, owing to stable atmospheric condition, multiphase reactions like in-cloud processes would be exacerbated, which further accelerated the generation of SOC [29]. EFs of POC in $\mathrm{PM}_{1}$ on MP and HP were 1.75 and 3.06, respectively, while those of SOC were 1.46 and 3.47. In term of $\mathrm{PM}_{2.5}$, EFs of POC were 1.67 and 2.54, while those of SOC were 1.54 and 3.20. Clearly, the growth rate of SOC in $\mathrm{PM}_{2.5}$ on polluted days is comparable to that in $\mathrm{PM}_{1}$, thus, we speculated that the SOC growth rates in $\mathrm{PM}_{1}$ and $\mathrm{PM}_{1-2.5}$ were similar, which could be related to the bimodal distribution of carbon components in particulate matter. Zhang's research [43] have shown that the distribution of carbon components in particulate matter is bimodal, and the peak particle size is located on both sides of $1 \mu \mathrm{m}$.

\subsection{The Impact of Aerosol Feedback}

Owing to the influence of aerosols absorbing and scattering of solar radiation, the amount of solar radiation reaching the Earth's surface may be affected, which results in the change of the meteorological factors, such as T2, PBLH, RH and WS. For illustrating how feedback effect on meteorological factors, we estimated the change of PBLH, T2, WS and RH between BASE and NF scenarios in percentage. Figure 6a presented differences of $\mathrm{PM}_{2.5}$ concentration and meteorological factors between the BASE and NF scenarios. We also summarize the distinction between the two simulations under three $\mathrm{PM}_{2.5}$ concen- 
trations ranges to comprehend the aerosol concentration influence as the same method in Chapter 3.1, i.e., $<75 \mu \mathrm{g} / \mathrm{m}^{3}$ (NP), $75-150 \mu \mathrm{g} / \mathrm{m}^{3}$ (MP) and $>150 \mu \mathrm{g} / \mathrm{m}^{3}(\mathrm{HP})$.

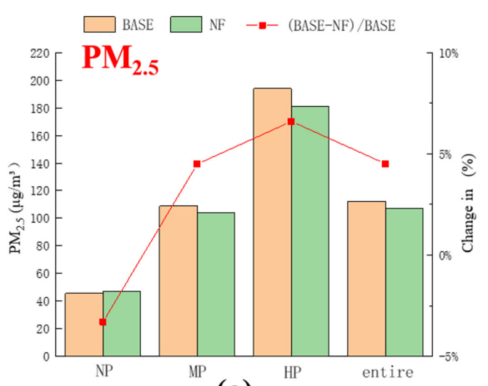

(a)

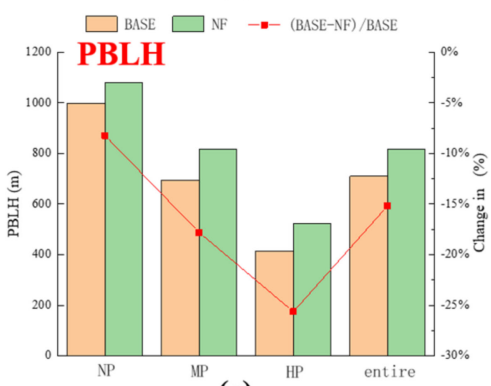

(c)

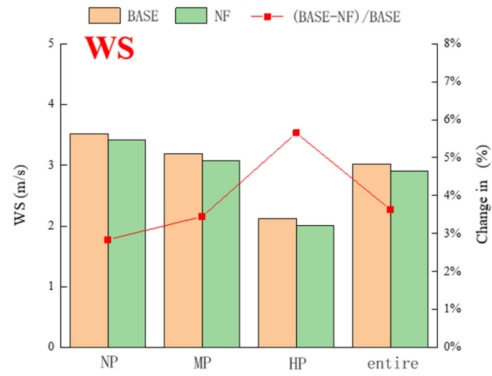

(e)

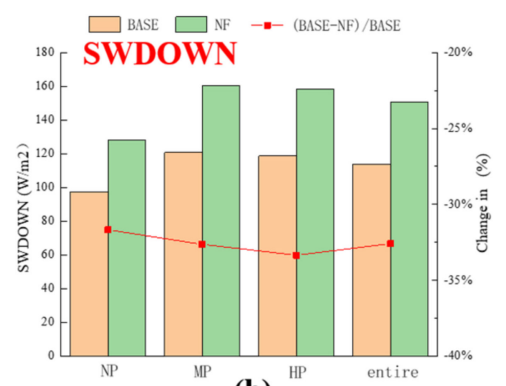

(b)
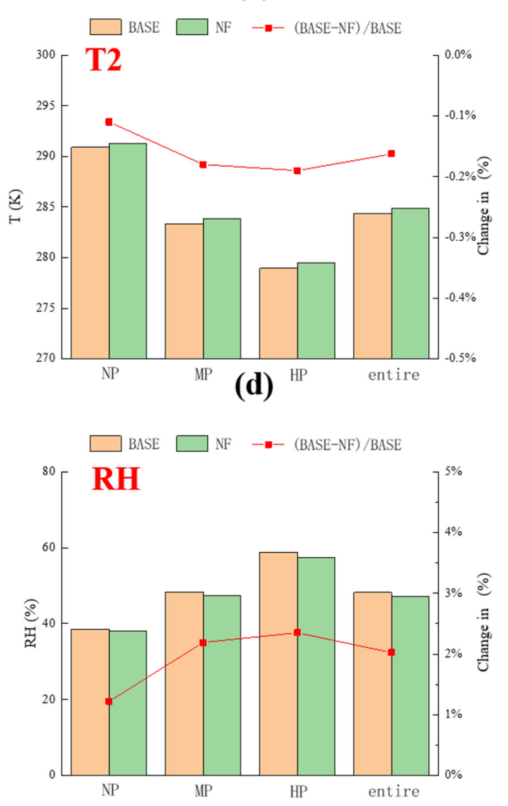

(f)

Figure 6. Changes of simulated aerosols feedback effect on $\mathrm{PM}_{2.5}(\mathbf{a}), \operatorname{SWDOWN}(\mathbf{b}), \mathrm{PBLH}(\mathbf{c}), \mathrm{T} 2$ (d), WS (e) and RH (f) in percentage on non-pollution, mild-moderate pollution and heavy pollution in Handan during the investigation period.

Comparing the BASE and the NF simulations, we can find that the higher $\mathrm{PM}_{2.5}$ concentration, the influence of aerosol feedback was more obvious. First of all, the concentration change of $\mathrm{PM}_{2.5}$ was most conspicuous in $\mathrm{HP}$, those effects for $\mathrm{PM}_{2.5}$ may reach as high as $6.6 \%\left(12.8 \mu \mathrm{g} / \mathrm{m}^{3}\right)$ in $\mathrm{HP}$, which was noteworthy in prediction and prevention of $\mathrm{PM}_{2.5}$. While in MP, impacts of aerosol feedback could prompt concentrations of $\mathrm{PM}_{2.5}$ raise by $4.5 \%\left(4.9 \mu \mathrm{g} / \mathrm{m}^{3}\right)$. It's remarkable that, in NP, the aerosol feedbacks lead to a mild decrease in Handan $\left(-3.30 \%,-1.5 \mu \mathrm{g} / \mathrm{m}^{3}\right)$, which indicates that the inhibition of $\mathrm{PM}_{2.5}$ concentrations resulted from the decrease in wind speed and atmospheric oxidation, conversely, the lower PBLH under clean days will promote $\mathrm{PM}_{2.5}$ increase.

This can be explained by that the aerosol feedbacks will reduce the solar radiation and thus lead to reduction of PBLH, it will aggravate pollutant accumulation. Meanwhile, the aerosol feedbacks may decrease the pollutant concentrations via changing wind field [44]. In addition, the reduction of radiation will result in a temperature decrease and concentrations of oxidant such as $\mathrm{HO}, \mathrm{HO}_{2}$ and $\mathrm{O}_{3}$, which will inhibit the formation of secondary aerosol [45]. It can be summarized that the aerosol feedbacks will exacerbate the urban $\mathrm{PM}_{2.5}$ pollution during severe polluted period, but at the same time, when concentrations of $\mathrm{PM}_{2.5}$ was low, those effects will obviously decreased. As a consequence from the influence of aerosol feedbacks, $\mathrm{PM}_{2.5}$ concentrations would increase by $4.51 \%\left(5.1 \mu \mathrm{g} / \mathrm{m}^{3}\right)$ during entire days in Handan. 
As shown in Figure $6 b-f$, results of the BASE and the NF simulations demonstrated that the aerosol radiative effects would bring about an average $32.6 \%\left(36.2 \mathrm{~W} / \mathrm{m}^{2}\right)$ decrease in SWDOWN, an average $17.5 \%(39.2 \mathrm{~m})$ and $0.16 \%(0.44 \mathrm{~K})$ decrease in PBLH and T2 over Handan. The WS and RH will be increased by about $4.16 \%(0.11 \mathrm{~m} / \mathrm{s})$ and $1.89 \%(0.78 \%)$, respectively. The PBL height reduced by $27.4 \mathrm{~m}, 41.2 \mathrm{~m}$ and $35.5 \mathrm{~m}$, accounted for $8.24 \%$, $17.8 \%$ and $25.6 \%$ in NP, MP and HP, respectively. It can be found that the PBLH decrease in heavy pollution days was more pronounced, which can be attributed to the high aerosol concentrations. It is worth noting that PBL became more stable caused by reduction of PBLH, and finally further inhibited the diffusion of pollutants in Handan where serious pollution already exited. The influence of aerosol radiation on $\mathrm{RH}$ and WS is not strong as its impact on PBLH and solar radiation. As a consequence, the RH of the Handan increased $1.22 \%, 2.35 \%$ and $2.19 \%$ in NP, MP and $\mathrm{HP}$, respectively. With WS increased $2.84 \%, 3.45 \%$ and $5.56 \%$. The relative reduction in T2 was much weaker compared with Other meteorological elements, the average T2 decreases of $0.11 \%, 0.18 \%$ and $0.19 \%$ in NP, $\mathrm{MP}$ and $\mathrm{HP}$, respectively. In conclusion, the more serious the pollution, the more obvious the effect of feedback on Meteorological parameters.

\section{Conclusions}

The distinction of $\mathrm{PM}_{1}$ and $\mathrm{PM}_{2.5}$ in clean and polluted days was discussed in this study, $\mathrm{PM}_{1}$ on non-pollution, mild-moderate pollution and heavy pollution were 34.8 , 80.1 and $166 \mu \mathrm{g} / \mathrm{m}^{3}$ while those of $\mathrm{PM}_{2.5}$ were $51.6,114$ and $216 \mu \mathrm{g} / \mathrm{m}^{3}$, respectively. $\mathrm{PM}_{2.5}$ was mainly contributed by $\mathrm{PM}_{1}$ and the proportion of $\mathrm{PM}_{1}$ to $\mathrm{PM}_{2.5}$ increased on haze days, the corresponding ratios of $\mathrm{PM}_{1} / \mathrm{PM}_{2.5}$ on $\mathrm{NP}, \mathrm{MP}$ and $\mathrm{HP}$ were $0.67,0.70$ and 0.77 , respectively.

The total water-soluble inorganic ions (TWSI) were the major chemical species for $\mathrm{PM}_{1}$ and $\mathrm{PM}_{2.5}$, accounted for $43.2 \%$ and $41.8 \%$ in $\mathrm{PM}_{1}$ and $\mathrm{PM}_{2.5}$. SNA $\left(\mathrm{SO}_{4}{ }^{2-}, \mathrm{NO}_{3}{ }^{-}\right.$ and $\mathrm{NH}_{4}{ }^{+}$) accounted more than $80 \%$ in TWSIs of both $\mathrm{PM}_{1}$ and $\mathrm{PM}_{2.5}$ on clean and polluted days, it is clear that SNA in $\mathrm{PM}_{1}$ on haze episodes increased more significant than in $\mathrm{PM}_{1-2.5}$. According to ratios of $\mathrm{NO}_{3}{ }^{-} / \mathrm{SO}_{4}{ }^{2-}$, we can infer that vehicles contributed much to $\mathrm{PM}_{2.5}$ and $\mathrm{PM}_{1}$ on polluted days. In this investigation, $\mathrm{SOR}$ in both $\mathrm{PM}_{1}$ and $\mathrm{PM}_{2.5}$ was higher than $\mathrm{NOR}$, and the value of $\mathrm{NH}_{4}{ }^{+} /\left(\mathrm{NO}_{3}{ }^{-}+\mathrm{SO}_{4}{ }^{2-}\right)$ in $\mathrm{PM}_{2.5}$ and $\mathrm{PM}_{1}$ demonstrating that $\mathrm{NH}_{4} \mathrm{NO}_{3}$ and $\left(\mathrm{NH}_{4}\right)_{2} \mathrm{SO}_{4}$ were major form of SNA.

During the campaign, OC and EC accounted for $15.4 \%$ and $16.0 \%$ in $\mathrm{PM}_{1}, 3.9 \%$ and $3.4 \%$ in $\mathrm{PM}_{2.5}$. OC and $\mathrm{EC}$ in $\mathrm{PM}_{1}$ or $\mathrm{PM}_{2.5}$ both had distinctly strong correlations, indicating these constituents might come from one or more co-genetic sources. POC in $\mathrm{PM}_{1}$ and in $\mathrm{PM}_{2.5}$ were 4.12 and 9.24, while SOC in $\mathrm{PM}_{1}$ and in $\mathrm{PM}_{2.5}$ were 7.54 and 8.29. It is obvious that OC/EC on haze days was higher than that on clean days in Handan, indicating that secondary formation of SOC might enhance haze events.

In severe polluted period aerosol feedback could exacerbate the urban $\mathrm{PM}_{2.5}$ pollution, while those effects was weaken as concentrations of $\mathrm{PM}_{2.5}$ was low. In conclusion, the more serious the pollution, the more obvious the effect of aerosol feedback on meteorological parameters. The results of the BASE and the NF simulations indicate that the aerosol radiative effects will result in an average $32.62 \%\left(36.18 \mathrm{~W} / \mathrm{m}^{2}\right)$ decrease in SWDOWN, an average $17.52 \%(39.15 \mathrm{~m})$ and $0.16 \%(0.44 \mathrm{~K})$ decrease in PBLH and T2 over Handan. The WS and RH will be increased by about $4.16 \%(0.11 \mathrm{~m} / \mathrm{s})$ and $1.89 \%(0.78 \%)$, respectively.

This study revealed the chemical characteristics of aerosol pollution including $\mathrm{PM}_{1}$ and $\mathrm{PM}_{2.5}$ in Handan, and evaluated the effect of aerosol feedback by WRF-Chem model. In addition, the aerosol-cloud-interaction should be further studied, and effects of precursors on particulate matter should be considered to effectively reduce the concentrations during heavily polluted days.

Supplementary Materials: The following are available online at https:/ /www.mdpi.com/article/10 .3390/atmos12060670/s1, Figure S1: Daily variation of observed data with simulated data during research period in Handan during the investigation period. 
Author Contributions: Data Analysis, S.Y., Q.W., J.Z.; Writing-original draft, S.Y.; Writing-edited draft, J.Z.; Investigation, R.Z. All authors have read and agreed to the published version of the manuscript.

Funding: This work was supported by the Science and Technology Planning Project of Henan Province, China (No. 212102310078), Natural Science Foundation of Henan Province, China (No. 212300410322), Soft Science Research Program of Henan Province, China (No. 202400410320).

Institutional Review Board Statement: Not applicable.

Informed Consent Statement: Not applicable.

Data Availability Statement: The data presented in this study are available on request from the corresponding author.

Acknowledgments: The authors are grateful to the anonymous reviewers for their insightful comments.

Conflicts of Interest: The authors declare no conflict of interest.

\section{References}

1. Gao, A.; Wang, J.; Luo, J.; Wang, P.; Zhang, H. Health and economic losses attributable to $\mathrm{PM}_{2.5}$ and ozone exposure in handan, china. Air Qual. Atmos. Health 2021, 14, 605-615. [CrossRef]

2. Wang, L.T.; Wei, Z.; Yang, J.; Zhang, Y.; Zhang, F.F.; Su, J.; Meng, C.C.; Zhang, Q. The 2013 severe haze over southern Hebei, China: Model evaluation, source apportionment, and policy implications. Atmos. Chem. Phys. 2014, 14, 3151-3173. [CrossRef]

3. Zhang, R.; Jing, J.; Tao, J.; Hsu, S.C.; Wang, G.; Cao, J.; Lee, C.S.L.; Zhu, L.; Chen, Z.; Zhao, Y.; et al. Chemical characterization and source apportionment of $\mathrm{PM}_{2.5}$ in Beijing: Seasonal perspective. Atmos. Chem. Phys. 2013, 13, 7053-7074. [CrossRef]

4. Zhang, F.; Wang, L.; Su, J.; Yang, J.; Wei, Z.; Meng, C.; Zheng, Y. Characteristics and Source Apportionment of Carbonaceous Species in $\mathrm{PM}_{2.5}$ of Handan City. Environ. Sci. Technol. 2015, 38, 94-100.

5. Li, H.; Zhang, Q.; Jiang, W.; Collier, S.; Sun, Y.; Zhang, Q.; He, K. Characteristics and sources of water-soluble organic aerosol in a heavily polluted environment in Northern China. Sci. Total Environ. 2020, 758, 143970. [CrossRef]

6. Luo, L.; Tian, H.; Liu, H.; Bai, X.; Liu, W.; Liu, S.; Wu, B.; Lin, S.; Zhao, S.; Hao, Y.; et al. Seasonal variations in the mass characteristics and optical properties of carbonaceous constituents of $\mathrm{PM}_{2.5}$ in six cities of North China. Environ. Pollut. 2021, 268 (Pt B), 115780. [CrossRef]

7. Sun, Y.; Du, W.; Wan, Q.; Zhang, Q.; Chen, C.; Chen, Y.; Chen, Z.; Fu, P.; Wang, Z.; Gao, Z.; et al. Real-Time Characterization of Aerosol Particle Composition above the Urban Canopy in Beijing: Insights into the Interactions between the Atmospheric Boundary Layer and Aerosol Chemistry. Environ. Sci. Technol. 2015, 49, 11340-11347. [CrossRef]

8. Zhang, H.; Cheng, S.; Li, J.; Yao, S.; Wang, X. Investigating the aerosol mass and chemical components characteristics and feedback effects on the meteorological factors in the Beijing-Tianjin-Hebei region, China. Environ. Pollut. 2019, 244, 495-502. [CrossRef]

9. Zhang, H.; Cheng, S.; Wang, X.; Yao, S.; Zhu, F. Continuous monitoring, compositions analysis and the implication of regional transport for submicron and fine aerosols in Beijing, China. Atmos. Environ. 2018, 195, 30-45. [CrossRef]

10. $\mathrm{Hu}, \mathrm{X}$.; Sun, J.; Xia, C.; Shen, X.; Zhang, S. Simultaneous measurements of $\mathrm{PM}_{1}$ and $\mathrm{PM}_{1} 0$ aerosol scattering properties and their relationships in urban beijing: A two-year observation. Sci. Total Environ. 2021, 770, 145215. [CrossRef]

11. Makar, P.A.; Gong, W.; Milbrandt, J.; Hogrefe, C.; Zhang, Y.; Curci, G.; Žabkar, R.; Im, U.; Balzarini, A.; Baró, R.J.A.E. Feedbacks between air pollution and weather, Part 1: Effects on weather. Atmos. Environ. 2015, 115, 442-469. [CrossRef]

12. Huang, K.; Zhuang, G.; Wang, Q.; Fu, J.S.; Lin, Y.; Liu, T.; Han, L.; Deng, C.J.A.C. Extreme haze pollution in Beijing during January 2013: Chemical characteristics, formation mechanism and role of fog processing. Atmos. Chem. Phys. Discuss. 2014, 14, 479-486.

13. Zheng, B.; Zhang, Q.; Zhang, Y.; He, K.B.; Wang, K.; Zheng, G.; Duan, F.K.; Ma, Y.L.; Kimoto, T.J.A.C. Heterogeneous chemistry: A mechanism missing in current models to explain secondary inorganic aerosol formation during the January 2013 haze episode in North China. Atmos. Chem. Phys. 2015, 14, 2031-2049. [CrossRef]

14. Zheng, G.J.; Duan, F.K.; Su, H.; Ma, Y.L.; Cheng, Y.; Zheng, B.; Zhang, Q.; Huang, T.; Kimoto, T.; Chang, D.J.A.C. Exploring the severe winter haze in Beijing: The impact of synoptic weather, regional transport and heterogeneous reactions. Atmos. Chem. Phys. 2015, 15, 2969-2983. [CrossRef]

15. Chen, D.; Liao, H.; Yang, Y.; Chen, L.; Wang, H. Simulated aging processes of black carbon and its impact during a severe winter haze event in the beijing-tianjin-hebei region. Sci. Total Environ. 2021, 755 (Pt 2), 142712. [CrossRef]

16. Wang, G.; Cheng, S.; Wei, W.; Yang, X.; Wang, X.; Jia, J.; Lang, J.; Lv, Z. Characteristics and emission-reduction measures evaluation of $\mathrm{PM}_{2.5}$ during the two major events: APEC and Parade. Sci. Total Environ. 2017, 595, 81-92. [CrossRef]

17. Wang, X.; Wei, W.; Cheng, S.; Li, J.; Zhang, H.; Lv, Z. Characteristics and classification of $\mathrm{PM}_{2.5}$ pollution episodes in Beijing from 2013 to 2015. Sci. Total Environ. 2018, 612, 170-179. [CrossRef]

18. Yang, X.; Cheng, S.; Lang, J.; Xu, R.; Lv, Z. Characterization of aircraft emissions and air quality impacts of an international airport. J. Environ. Sci. 2018, 72, 198-207. [CrossRef]

19. Zhou, Y.; Cheng, S.; Chen, D.; Lang, J.; Zhao, B.; Wei, W.J.A.E. A new statistical approach for establishing high-resolution emission inventory of primary gaseous air pollutants. Atmos. Environ. 2014, 94, 392-401. [CrossRef] 
20. Zhou, Y.; Cheng, S.; Lang, J.; Chen, D.; Zhao, B.; Liu, C.; Xu, R.; Li, T. A comprehensive ammonia emission inventory with high-resolution and its evaluation in the Beijing-Tianjin-Hebei (BTH) region, China. Atmos. Environ. 2015, 106, 305-317. [CrossRef]

21. Jia, J.; Cheng, S.; Yao, S.; Xu, T.; Zhang, T.; Ma, Y.; Wang, H.; Duan, W. Emission characteristics and chemical components of size-segregated particulate matter in iron and steel industry. Atmos. Environ. 2018, 182, 115-127. [CrossRef]

22. Zaveri, R.A.; Peters, L.K. A new lumped structure photochemical mechanism for large-scale applications. J. Geophys. Res. Atmos. 1999, 104, 30387-30415. [CrossRef]

23. Zaveri, R.A.; Easter, R.C.; Fast, J.D.; Peters, L.K. Model for Simulating Aerosol Interactions and Chemistry (MOSAIC). J. Geophys. Res. Atmos. 2008, 113. [CrossRef]

24. Chou, M.D.; Suarez, M.J.; Ho, C.H.; Yan, M.M.H.; Lee, K.T. Parameterizations for cloud overlapping and shortwave singlescattering properties for use in general circulation and cloud ensemble models. J. Clim. 1998, 11, 202-214. [CrossRef]

25. Mlawer, E.J.; Taubman, S.J.; Brown, P.D.; Iacono, M.J.; Clough, S.A. Radiative transfer for inhomogeneous atmospheres: RRTM, a validated correlated-k model for the longwave. J. Geophys. Res. Atmos. 1997, 102, 16663-16682. [CrossRef]

26. Hong, S.Y. A new vertical diffusion package with an explicit treatment of entrainment processes. Mon. Weather Rev. 2006, 134, 2318-2341. [CrossRef]

27. Wang, Y.Q.; Zhang, X.Y.; Sun, J.Y.; Zhang, X.C.; Che, H.Z.; Li, Y.J.A.C. Spatial and temporal variations of the concentrations of $\mathrm{PM}_{10}, \mathrm{PM}_{2.5}$ and $\mathrm{PM}_{1}$ in China. Atmos. Chem. Phys. Discuss. 2015, 15, 3585-13598.

28. Li, B.; Zhang, J.; Zhao, Y.; Yuan, S.; Zhao, Q.; Shen, G.; Wu, H. Seasonal Variation of Urban Carbonaceous Aerosols in a Typical City Nanjing in Yangtze River Delta, China. Atmos. Environ. 2015, 106, 223-231. [CrossRef]

29. Tian, S.; Pan, Y.; Liu, Z.; Wen, T.; Wang, Y. Size-resolved aerosol chemical analysis of extreme haze pollution events during early 2013 in urban Beijing, China. J. Hazard. Mater. 2014, 279, 452-460. [CrossRef] [PubMed]

30. Zhao, L.; Wang, L.; Tan, J.; Duan, J.; Ma, X.; Zhang, C.; Ji, S.; Qi, M.; Lu, X.H.; Wang, Y.; et al. Changes of chemical composition and source apportionment of $\mathrm{PM}_{2.5}$ during 2013-2017 in urban handan, china. Atmos. Environ. 2019, 206, 119-131. [CrossRef]

31. Huang, T.; Chen, J.; Zhao, W.; Cheng, J.; Cheng, S.J.A. Seasonal Variations and Correlation Analysis of Water-Soluble Inorganic Ions in $\mathrm{PM}_{2.5}$ in Wuhan, 2013. Atmosphere 2016, 7, 49. [CrossRef]

32. Sun, Y.L.; Zhuang, G.S.; Tang, A.H.; Wang, Y.; An, Z.S. Chemical characteristics of $\mathrm{PM}_{2.5}$ and $\mathrm{PM}_{10}$ in haze-fog episodes in Beijing. Environ. Sci. Technol. 2006, 40, 3148-3155. [CrossRef]

33. Zhang, P.; Tan, S.; Wang, L.; Zhao, X.; Su, J.; Zhang, F.; Wei, Z.; Wei, W.; Cheng, D. Characteristics of atmospheric particulate matter pollution in Handan City. Acta Sci. Circum. 2013, 33, 2679-2685.

34. Ma, J.; Chu, B.; Liu, J.; Liu, Y.; Zhang, H.; He, H. NO promotion of $\mathrm{SO}_{2}$ conversion to sulfate: An important mechanism for the occurrence of heavy haze during winter in Beijing. Environ. Pollut. 2018, 233, 662-669. [CrossRef]

35. Shi, Y.; Chen, J.; Hu, D.; Wang, L.; Yang, X.; Wang, X. Airborne submicron particulate (PM 1 ) pollution in Shanghai, China: Chemical variability, formation/dissociation of associated semi-volatile components and the impacts on visibility. Sci. Total Environ. 2014, 473, 199-206. [CrossRef]

36. Zhou, G.; Yang, F.; Geng, F.; Xu, J.; Yang, X.; Tie, X. Measuring and Modeling Aerosol: Relationship with Haze Events in Shanghai, China. Aerosol Air Qual. Res. 2014, 14, 783-792. [CrossRef]

37. Lee, H.-J.; Jo, H.-Y.; Song, C.-H.; Jo, Y.-J.; Park, S.-Y.; Kim, C.-H. Sensitivity of Simulated PM2.5 Concentrations over Northeast Asia to Different Secondary Organic Aerosol Modules during the KORUS-AQ Campaign. Atmosphere 2020, 11, 1004. [CrossRef]

38. Liu, Z.; Xie, Y.; Hu, B.; Wen, T.; Xin, J.; Li, X.; Wang, Y. Size-resolved aerosol water-soluble ions during the summer and winter seasons in beijing: Formation mechanisms of secondary inorganic aerosols. Chemosphere 2017, 183, 119-131. [CrossRef]

39. Turpin, B.J.; Lim, H.J. Species contributions to $\mathrm{PM}_{2.5}$ mass concentrations: Revisiting common assumptions for estimating organic mass. Aerosol Sci. Technol. 2001, 35, 602-610. [CrossRef]

40. Cao, J.J.; Lee, S.C.; Ho, K.F.; Zhang, X.Y.; Zou, S.C.; Fung, K.; Chow, J.C.; Watson, J.G. Characteristics of carbonaceous aerosol in Pearl River Delta Region, China during 2001 winter period. Atmos. Environ. 2003, 37, 1451-1460. [CrossRef]

41. Zhang, Y.Y.; Müller, L.; Winterhalter, R.; Moortgat, G.K.; Hoffmann, T.; Pöschl, U. Seasonal cycle and temperature dependence of pinene oxidation products, dicarboxylic acids and nitrophenols in fine and coarse air particulate matter. Atmos. Chem. Phys. 2010, $112,213-215$.

42. Feng, J.; Li, M.; Zhang, P.; Gong, S.; Zhong, M.; Wu, M.; Zheng, M.; Chen, C.; Wang, H.; Lou, S. Investigation of the sources and seasonal variations of secondary organic aerosols in $\mathrm{PM}_{2.5}$ in Shanghai with organic tracers. Atmos. Environ. 2013, 79, 614-622. [CrossRef]

43. Zhang, J.; Tong, L.; Huang, Z.; Zhang, H.; He, M.; Dai, X.; Zheng, J.; Xiao, H. Seasonal variation and size distributions of water-soluble inorganic ions and carbonaceous aerosols at a coastal site in Ningbo, China. Sci. Total Environ. 2018, 639, 793-803. [CrossRef] [PubMed]

44. Gao, M.; Carmichael, G.R.; Saide, P.E.; Lu, Z.; Yu, M.; Streets, D.G.; Wang, Z. Response of winter fine particulate matter concentrations to emission and meteorology changes in North China. Atmos. Chem. Phys. 2016, 16, 11837-11851. [CrossRef]

45. Gao, J.; Tian, H.; Cheng, K.; Lu, L.; Zheng, M.; Wang, S.; Hao, J.; Wang, K.; Hua, S.; Zhu, C.; et al. The variation of chemical characteristics of $\mathrm{PM}_{2.5}$ and $\mathrm{PM}_{1} 0$ and formation causes during two haze pollution events in urban Beijing, China. Atmos. Environ. 2015, 107, 1-8. [CrossRef] 